\title{
The Effect of Recombinant Vascular Endothelial Growth Factor (VEGF)-121 Towards Placenta Growth Factor Serum Levels in Female Mice (Mus Musculus) with Preeclampsia Model
}

\author{
Wisnu Prabowo \\ Department of Obstetrics and Gynecology, Dr. Moewardi Hospital, Surakarta, \\ Central Java, Indonesia
}

\section{ABSTRACT}

Background: Preeclampsia is a multi systemic disease which recognized by the development of hypertension after 20 weeks of gestation with the presence of proteinuria or any signs indicative of target organ injury. The correct diagnosis and classification of the disease are essential since the therapies are unique in each class. Moreover, the angiogenic factors claims to play a significant role in the endothelial injury which plays as an etiology for preeclampsia. Thus, this study aimed to analyze the differences between angiogenic factors in pregnancy mice with preeclampsia models after administration of VEGF-121.

Subjects and Method: Subject of the study were swiss's strains of pregnancy mice (Mus musculus) which divided into three groups that consist of 10 subject of study in each group. Subjects for this research were recruited between March and May 2015 in Biomedical Laboratory of The Faculty of Veterinary Medicine, Universitas Airlangga as part of a cross sectional study designed for analytical experimental. The angiogenic factor which measured was PIGF serum levels with ELISA method and only group of pregnant mice with preeclampsia model which administred with injection of VEGF-121.

Results: This study was conducted of 30 male and 30 female Mus musculus with homogeneous characteristic in terms of age, average body weight and have never been pregnant before. The differences in PIGF serum levels between three observed group are significant $(\mathrm{p}=0.035)$.

Conclusion: Administration of VEGF-121 increased the PlGF serum levels in pregnant mice with preeclampsia model. Thus, the administration of VEGF-121 improves the condition of endothelial damage in preeclampsia with an increase in PlGF levels.

Keywords:

angiogenic factors, preeclampsia, placenta growth factor, VEGF-121.

\section{Correspondence:}

Wisnu Prabowo. Department of Obstetrics and Gynecology, Dr. Moewardi Hospital. Kolonel Sutarto 132, Jebres, Surakarta, Central Java, Indonesia. Email: wisnuprabowofetomaternal@gmail.com. Mobile: +6281390015151.

\section{Cite this as:}

Prabowo W (2021). The Effect of Recombinant Vascular Endothelial Growth Factor (VEGF)-121 Towards Placenta Growth Factor Serum Levels in Female Mice (Mus Musculus) with Preeclampsia Model. J Matern Child Health. 06(03): 339-343. https://doi.org/10.26911/thejmch.2021.06.03.08. cc) (i) (2) Journal of Maternal and Child Health is licensed under a Creative Commons

\section{BACKGROUND}

The etiology of preeclampsia remains unclear. Moreover, the presence of endothelial dysfunction plays a role in the development of disease. The target of SDGs are expected thatmaternal mortality rate will be reduced to $50 \%$, thus, the adequate management of hypertension cases in pregnancy is needed.

An imbalance between angiogenic factors in the pathogenesis of preeclampsia is responsible for the preeclampsia syndrome. According to Levine (2006) reported that an increase in soluble-Fms- 
like Tyrosinekinase-1(sFlt-1) was due to a decrease in free PIGF in preeclamptic as a response for endothelial dysfunction. Several studiesreported that treatment of preeclampsia before clinical symptoms (subclinical) appear in experimental animals that VEGF signaling pathway which targets VEGF-121 in therapy for preeclampsia and forms the basis of further research into preeclamptic disease.

Thus, this research aims to analyze the differences of angiogenic factors in pregnancy mice after administration of VEGF-121 and to know about the function of VEGF-121 as the potential therapy on pregnancy mice with preeclampsia model.

\section{SUBJECTS AND METHOD}

\section{Study Design}

Subjects for this study were recruited between March and May 2015 in The Biomedical Laboratory of the Faculty on Veterinary Medicine, Universitas Airlangga as part of a cross sectional study designed for analytical experimental.

\section{Population and Sample}

Subject of this research fulfilled the inclusion criteria wereswiss's strains of Mus musculus female mice. Based on performed sampling technique (Hanafiah KA, 2004) known that each categorized group was 8.5 $(n=9)$. Moreover, the number of samples for each group was increased to 10 oso that the total sample of this research are 30 mice. The decision are taken into consideration to avoid in reducing of the number of subjects due to death, illness, mice who experienced premature labor and weight loss during this researh.

\section{Study Variables}

The dependent variable which observed in this research were the PIGF serum levels in the blood vessels of the pregnanct mice. Moreover, the independent variable were the administration of VEGF-121 to pregnant mice with preeclampsia model. Meanwhile, this research aim to have standarize subject which were carried by the control variable that consist of type of the mice (Mus musculus), sex (Female), body weight (2025 grams), given food, drink and the feeding time, environmental factors (cage sanitation, temperature and humidity of the cage)

\section{Operational Definition of Variables}

The PIGF serum levels is the factor proangiogenesiswhich circulate in the maternal circulation. The levels can be checked in the maternal blood plasma using the ELISA method. Meanwhile, the VEGF-121 is the protein of pro-angiogenicwhich plays a role in the processes ofvasculogenesis, angiogenesis, and a receptor on the endothelial wall, namely VEGR-1 and can also bind to a stronger bond to sFlt-1.

\section{Study Instruments}

Angiogenic factor was measured by PIGF Kit (Elissa) and Anti Qa2 Kit. Administration of VEGF-121 was measured by Recombinant VEGF-121. Female mice was measured with Pregnant More Serum Gonadotropin (PMSG) and Human Chorionic Gonadotropin (HCG). All subject were going into surgery as an induction for the pregnancy and pregnancy with preeclampsia model (Figure 1).

\section{Data analysis}

The homogeneity between experimental and control groups was tested using Normality Test. Moreover, the comparison between observed variables were tested by One-Way Anova Test.

\section{Research Ethics}

Research ethical issues including informed consent, anonymity, and confidentiality, were addressed carefully during the study process. The research ethical clearance approval letter was obtained from the Animal Care and Use Committee (ACUC) at Faculty on Veterinary Medicine, Univer- 
sitas Airlangga, Indonesia with approval number on 421-KE-2015 in March 18, 2015.

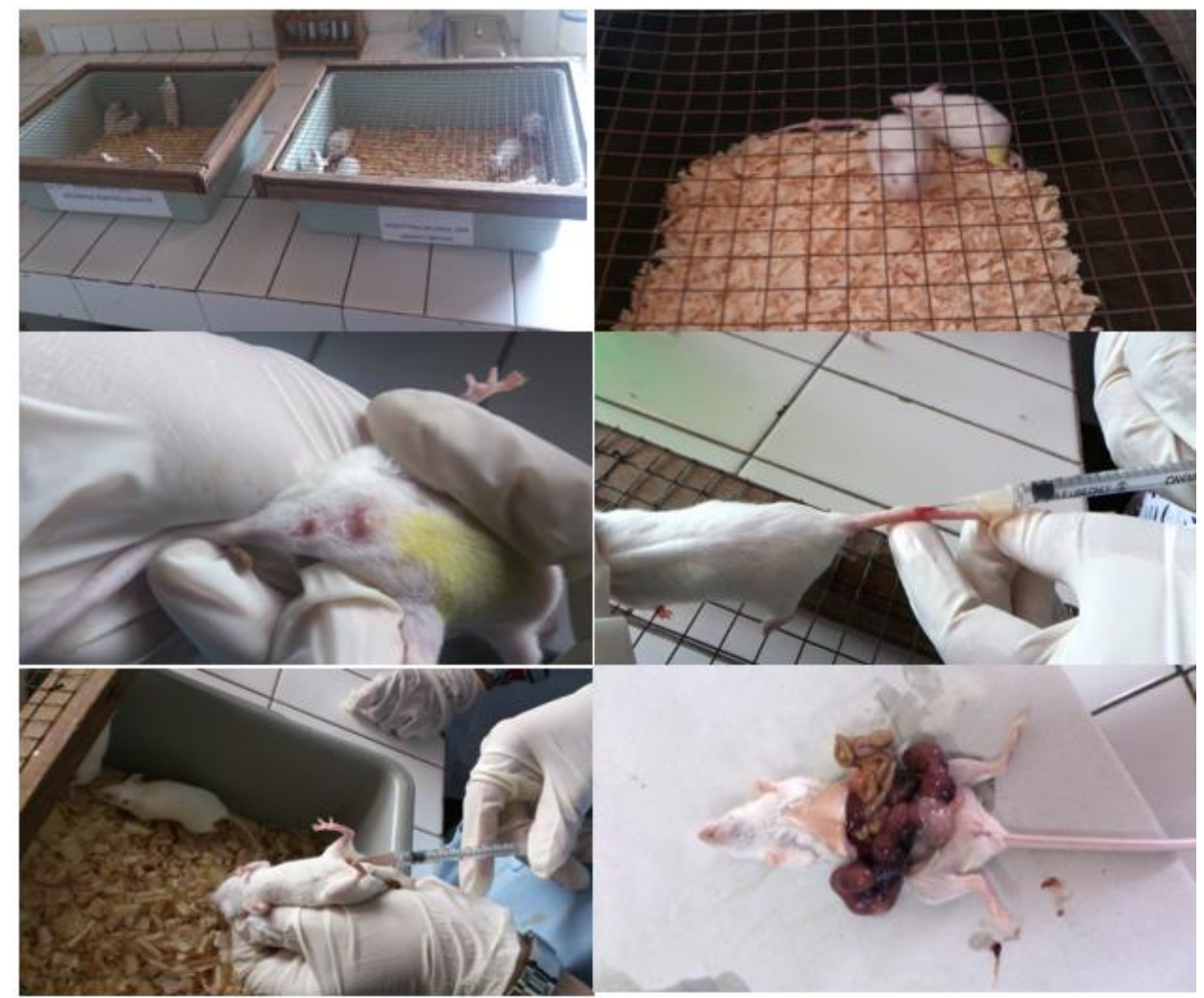

Figure 1. Subject preparation

\section{RESULTS}

\section{Sample Characteristics}

This study were conducted of 30 male and 30 female Mus musculus with homogeneous characteristic in terms of age, average body weight and have never been pregnant before. The action of surgery aims for the induction of pregnancy with PMSG and Table 1. Sample charateristics (continous data)

\begin{tabular}{lcccc}
\hline \multicolumn{1}{c}{ Group } & Mean & SD & Min. & Max. \\
\hline Normal & 1127.80 & 8.61 & 910.0 & 1411.7 \\
Preeclampsia & 838.70 & 9.53 & 466.7 & 1353.3 \\
VEGF Therapy & 1305.4 & 14.42 & 875.07 & 11748.4 \\
\hline
\end{tabular}

\section{Bivariate Analysis}

This research evaluated the effect after administration VEGF-121 in pregnancy mice with preeclampsia model. Thus, this research were divided into three groups (normal pregnancy, pregnancy with preeclampsia, and preeclampsia with administrasion of VEGF-121). The evaluation were
hCG. Thus, this study divided into three groups with 9 units of female mice with normal pregnancy (K1), 9 units of pregnancy mice with preeclampsia model (K2) and 9 units of pregnancy mice with preeclampsia model on adminstration of VEGF-121 injections (K3)(Table 1). 
Prabowo et al./ Recombinant VEGF-121 Towards Placenta Growth Factor Serum Levels

Table 2. Bivariat analysis on PIGF serum levels between three observed groups

\begin{tabular}{cccccc}
\hline Group & Mean & SD & Min. & Max. & p \\
\hline Normal & $1,127.78$ & 224.03 & 910.00 & $1,411.70$ & \\
Preeklampsia & 838.70 & 306.24 & 466.70 & $1,353.30$ & 0.035 \\
VEGF Therapy & $1,305.37$ & 493.58 & 875.00 & $2,181.67$ & \\
\hline
\end{tabular}

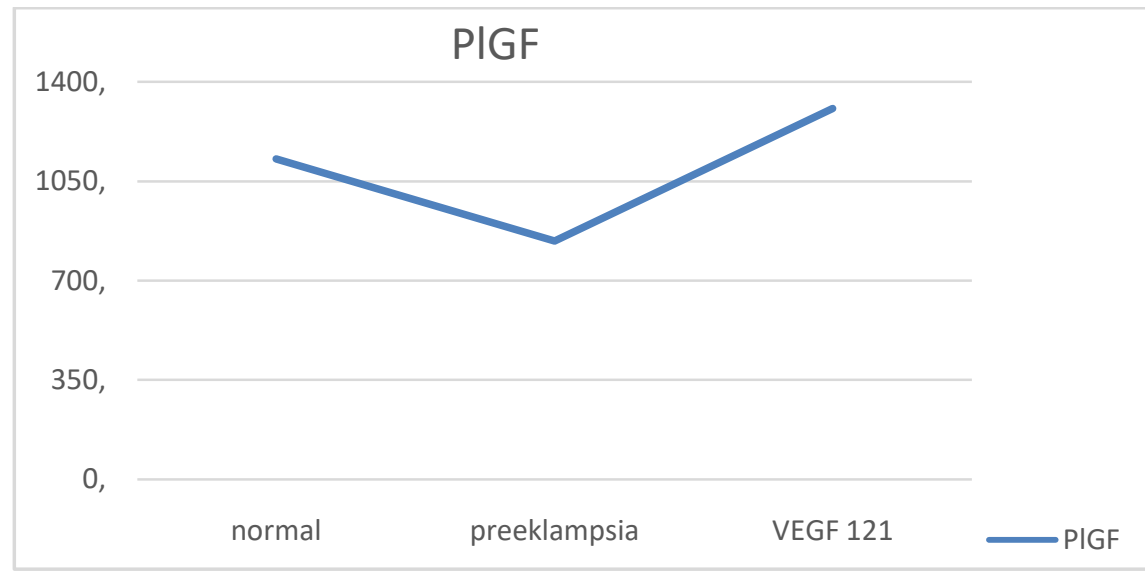

Figure 2. PIGF serum levels profile on each observed groups

\section{DISCUSSION}

The homogeneity of subjects were measured on chosen gender, age and body weight. The synchronization process of lust and monomating were performed. The first day of pregnancy was diagnosed when a copulatory plug was found in the vagina of the mated female mice (Mus musculus). This research consist of 30 pregnancy mice which divided into three observed groups. Blood samples were taken for measurement of PIGF serum levels using the ELISA method.

VEGF-121 is one of the type for external VEGF. It is already reported that VEGF binds to sFLt1 so that the action of PlGF as a proangiogenetic factors is not disturbed (Sidiqqui 2012). VEGF-121 in pregnant mice can reduce angiotensin type 1 which triggers hypertension and proteinuria. Neutralizes the effect of increasing sFlt-1 in preeclampsia will be decreasing the binding between sFlt-1 and PIGF. Thus, the PIGF serum levels returns to normal. Study reported that VEGF 121 binds to
VEGFR-1 to trigger angiogenetic process. This study aims to know about the function of VEGF 121 which came to conclusion that VEGF 121 prevents the onset of clinical symptoms of preeclampsia. This mechanism were triggered by high levels of sFlt-1 in pregnancy mice with preeclampsia model. Based on the function of VEGF which can trigger the angiogenetic factor, VEGF-121 can also categorized as the endogenous VEGF,

The administration of VEGF-121 increased the PIGF serums level in mice with preeclampsia model. Thus, improved the condition of endothelial damage by increasing the levels of PIGF.

Further study necessarily to examine sFlt-1 as a marker of the balance factor of angiogenectic in preeclampsia. Also, the administration of VEGF-121 on the placenta tissue need to be more carefully conducted to determine the effect of further vascular endothelial repair and to optimization the role of VEGF-121 as potential therapy. 


\section{AUTHOR CONTRIBUTION}

Wisnu Prabowo was the main researcher who collected data, formulated data, designed research and conducted questionnaire realibiy test and analyze the data.

\section{CONFLICT OF INTEREST}

The author declare that the study was conducted in the absence of any commercial of financial relationshops that could be construed as a potential conflict of interest.

\section{FUNDING AND SPONSORSHIP}

None.

\section{ACKNOWLEGMENT}

The author would like to adress for distinguished opportunity to all parties involved during conducted research studies.

\section{REFERENCES}

Ananth K, Bdolah Y, et al. (2004). Angiogenic Imbalance in the Pathophysiology of Preeclampsia: Newer Insights. Semin Nephrol. 24: $548-556$.

Chaiworapongsa T, Romero R, Kim YM, Kim GJ, Kim MR, Espinoza J, Bujold E, Gonçalves L, et al. (2005). Plasma soluble vascular endothelial growth factor receptor-1 concentration is elevated prior to the clinical diagnosis of pre-eclampsia. J Matern Fetal Neonatal Med. 17(1):3-18. https://doi.org/10.1080/1476705040002881 6.

Chen and Novel (2009).Angiogenic Factors for Predicting Preeclampsia: sFlt-1, PlGF, and Soluble Endoglin. Clinical Chemistry Journal. 2:1- 6.

Comiskey M, Warner C, Schust D (2006). MHC molecules of the preimplanta- tion embryo and trophoblast. Immunology of pregnancy. 16:130-142. https://www.ncbi.nlm.nih.gov/books /NBK6277/.

Creasy R (2014). Maternal Fetal Medicine, Principle and Practice.7:756.

Cuningham (2013). William Obstetric. Twenty fifth Edition. MD: Lippincot Williams \& Wilkins. $762-763$.

Gilbert J., et al. (2010). Recombinant Vascular Endothelial Growth Factor 121 Infusion Lowers Blood Pressure and Improves Renal Function in Rats With Placental Ischemia-Induced Hypertension. Hypertension. 55:380385 .

Hagmann H, Thadhani R, Benzing T, Karumanchi SA, Stepan H (2012). The promise of angiogenic markers for the early diagnosis and prediction of preeclampsia. Clin Chem. 58(5): 83745. https://doi.org/10.1373/clinchem.2011.169094.

Herse F, Verlohren S, Wenzel K, Pape J, Muller DN, Modrow S, Wallukat G, Luft FC, et al. (2009). Prevalence of agonistic autoantibodies against the angiotensin II type 1 receptor and soluble fms-like tyrosine kinase 1 in a gestational age-matched case study. Hypertension. 53(2): 393-398. https://doi.org/10.1161/hypertensionaha.10 8.124115 .

Holston A, Qian C, Yu KF, Epstein FH, Karumanchi SA, Levine RJ (2009). Circulating angiogenic factors in gestational proteinuria without hypertension. Am J Obstet Gynecol. 200(4): 390-392. https://doi.org/10.1016/j.ajog.2008.10.033.

Karumanchi SA, Bdolah Y (2004). Hypoxia and sFlt-1 in Preeclampsia: The "Chicken-and Egg" Question. Endocrinology. 145(11): 4835-4837. https://doi.org/10.1210/en.2004-1028. 
Karumanchi A, Karumanchi SA, Lafayette R (2007). Pathophysiology of the clinical manifestations of preeclampsia. Clin J Am Soc Nephrol. 2(3): 543-549. https://doi.org/10.2215/cjn.03761106 Karumanchi A, Nien JK, Espinoza J, Todem $\mathrm{D}, \mathrm{Fu} \mathrm{W}$, Chung H, Kusanovic JP, et al. (2008). A longitudinal study of angiogenic (placental growth factor) and anti-angiogenic (soluble endoglin and soluble vascular endothelial growth factor receptor-1) factors in normal pregnancy and patients destined to develop preeclampsia. $\mathrm{J}$ Matern Fetal Neonatal Med. 21(1): 923. https://doi.org/10.1080/14767050701830480.

Levine R, Maynard SE, Qian C, Lim KH, England LJ, Yu KF, Schisterman EF, Thadhani R, et al. (2004). Circulating angiogenic factor and the risk of preeclampsia. N Engl J Med. 350(7): 672-683. https://doi.org/10.1056/nejmoao31884.

Levine R, Lam C, Qian C, Yu KF, Maynard SE, Sachs BP, Sibai BM, Epstein FH, et al. (2006). Soluble endoglin and other circulating antiangiogenic factors in preeclampsia. N Engl J Med. 355(10): 992-1005. https://doi.org/10.1056/nejmoao55352.

Li Z, Zhang Y, Ma JY, Kapoun AM, Shao Q, Kerr I, Lam A, et al. (2007). Recombinant vascular endothelial growth factor 121 attenuates hypertension and improves kidney damage in a rat model of preeclampsia. Hypertension. 50(4): 686-692. https://doi.org/10.1161/hypertensionaha.107.092098.

Poon LC, Nicolaides KH (2014). Early prediction of preeclampsia. Obstet Gynecol Int. 2014: 297397. https://dx.doi.org/10.1155\%2F2O14\%2F297397.

Perkin E, et al. (2011). First trimester prediction of preeclampsia. Delfia Express PlGF Assay. 11:120

Shah DM (2007). Preeclampsia: new insight, Curr Opin Nephrol Hypertens. 16(3): 213-20. https://doi.org/10.1097/mnh.obo13e3280d942e9.

Siddiqui A, Irani RA, Zhang Y, Dai Y, Blackwell SC, Ramin SM, Kellems RE, Xia Y (2011). Recombinant vasculer endothelial growth factor 121 attenueates autoantibody induced feature of preeclampsia in pregnant mice. Am J Hypertens. 24(5): 606-12. https://doi.org/10.1038/ajh.2010.247.

Sulistyowati S, Abadi A, Hood J, Soetjipto (2010). The influence of low HLA-G protein expression on HSP-70 and VCAM-1 profile in preeclampsia. Indones J Obstet Gynecol. 34(4): 185190. http://inajog.com/index.php/journal/article/view/301/290.

Wang A, Rana S, Karumanchi SA (2009). Preeclampsia: The role of angiogenic factor in its pathogenesis. Am Physiol. 24: 147-15. https://doi.org/10.1152/physiol.00043.2008. 